\title{
Translation of Ellipsis as a Stylistic Feature: Hemingway's The Old Man and the Sea and Its Persian Translations
}

\author{
Arezou Nezam \\ University of Isfahan, Iran \\ Email: a.nezam1987@gmail.com \\ Hossein Pirnajmuddin \\ English Department, University of Isfahan, Iran \\ Email: pirnajmuddin@ fgn.ui.ac.ir
}

\begin{abstract}
Ellipsis, as a cohesive device in a text, has to be considered as an index of style in a literary text, hence a challenge for the literary translator who is supposed to render faithfully the style as the author's unique voice and the text's identity. This article aims at investigating the strategies adopted by Persian translators to render the elliptical patterns of Hemingway's masterpiece The Old Man and the Sea. It also tries to examine the effectiveness of using such strategies regarding the linguistic features of the target language. The model for analyzing the instances of ellipsis is that of the 8 main categories of frequent elliptical patterns as defined by Quirk et al (1985). Considering that English and Persian function quite similarly in most of these categories, it seems that the strategy of literal translation would be fairly efficacious in rendering this stylistic feature; also, expansion would help in cases where the two languages differ. The results showed that keeping the original style as closely as possible a few loyal translations have negotiated the two linguistic systems in terms of elliptical patterns. However, most Persian translators, inattentive to the style of the text have tended to interpret the pattern and expand the text, or simply delete the elliptical element whereby depriving the target reader from enjoying the author's genuine art.
\end{abstract}

Index Terms - ellipsis, literary translation, style, stylistics, The Old Man and the Sea

\section{INTRODUCTION}

"The study of translation is assuming a high profile, and what is remarkable is that this is happening not only in the traditional centers of the west, but world-wide" (Hatim, 2001, p. 9). In recent decades translations have proliferated in Iran. Literary translations account for a large part of this proliferation.

Karim Emami (1993), an Iranian translator and translation scholar, considers the act of translation as passing through a slippery narrow pass. Could one, he asks, walk a tightrope without any hazards? (p.33). Thus, a sophisticated translator, as the messenger, is supposed to explore the vast domain of ST, experience the unknown and find the safest way back home.

The literary translator has to face the double challenge of both rendering the content and form. Due to the fact that style is the very soul of an author's expression, understanding it and trying to render it as closely as possible is imperative in literary translation. But how style-conscious should a literary translator be? Fidelity is often cited as the measure of a successful translation. Weshler (1998), for instance, states that "fidelity is the most basic ethical term in translation" (p. 58). The necessity of fidelity to the style of a writer is of course taken for granted. But it is more preached about than practiced, as we are going to exemplify in the case of Persian translations of Hemingway.

Ernest Hemingway frequently uses elliptical patterns in his stories as an important feature of his style. His powerful style-forming mastery of the art of modern narration is evidenced in The Old Man and the Sea (Carey, 1973). Of his own style, he says that it is more suggestive than direct. The reader either has to use his imagination or lose the most subtle part of his thought (p. 55).

\section{BACKGROUND OF THE STUDY}

Literature and translation, two old companions, have been the subjects of numerous studies. As Habib puts it, "it has become indisputably clear that the study of humanities in general is no longer a luxury but a necessity, vital to our very survival as an enlightened civilization" (p. 1). Literature plays a vital role in negotiation among civilizations that can be reborn through the complicated process known as translation. In the words of Landers (2001), "a myriad of fine pieces of literature appearing in hundreds of languages is of the best argument for doing literary translations" (p. 5). Literary translation, particularly, plays a vital role in creating a rapprochement among cultures. Also it is a means of enriching 
literatures and cultures. In a complex work of literature, decisions made by the translator may unfold those of the author in the original work. This means that the translator hazards deviating from TL norms. Jones (2000) sees the translator as an ambassador who mediates between nations, representing the interests of his or her own country, but in a consonant manner with the understanding and outlook of the host country.

Literary translation has mostly presupposed a certain notion of 'literariness' within which it has been able to mark off its boundaries and to distinguish its sanctions, methods and approaches to its subject. In this regard, textual constituents tie together to make a dynamic environment that can change over time. However, with divergent interpretations of an individual text, the resonance of the original and its translated versions are never totally congruent and as a result, the notion of exact translation seems to be a debatable one. "Since no two languages are identical, either in the meanings given to corresponding symbols or in the ways in which such symbols are arranged in phrases and sentences, it stands to reason that there can be no absolute correspondence between two languages. Hence, there can be no fully exact translation" (Nida, cited in Venuti, 2004, p. 153). All in all, characterized by the openness and the complexity of man's experiences, a work of literature finds its identity through the mixture of form and content that needs to be highlighted during the process of translating and recreating a literary counterpart in TL.

Nabokov (cited in Venuti, 2000) believes that "the person, who desires to turn a literary masterpiece into another language, has only one duty to perform, and this is to reproduce with absolute exactitude the whole text and nothing but the text" (p. 121).

As language serves as a medium of communication as well as a means of shaping one's thoughts, style is viewed as the correspondence between thought and expression. Paired with the content the style of a work is essential and elemental. As Toolan (1990) puts it, "a general principle is asserted, namely that surface forms are systematically and predictably relatable to underlying abstract semantic contents" (p. 7). Style, then, is not superfluous decoration but rather a vehicle of meaning. As such, the art of the author manifests itself in communicating the richness of viewpoints, feelings and impressions that are not necessarily directly expressed. The challenge in literary translation is simply the choice among various means of rendering the original in a way as to exhibit these aspects through the target version. In this connection, Benjamin (cited in Venuti, 2004) contends that "A real translation is transparent; it does not cover the original, does not black its light, but allows the pure language, as though reinforced by its own medium to shine upon the original all the more carefully" (p. 81).

Hemingway's fiction is famous for its inimitable style. As Adams (1939) puts it, "no American writer of his generation has been more talked about than Ernest Hemingway. None has exerted a comparable influence upon still younger writers, none has raised higher hopes or caused greater misgivings regarding his future" (p. 87). Hemingway received the Nobel Prize for "his powerful style-forming mastery of the art of modern narration, evidenced in the Old Man and the Sea" (Carey, 1973: 8). Bloom (1987) considers him as "an elegant poet, who mourns the self, who celebrates the self (rather less effectively), and who suffers divisions in the self" (p. 3). His effect on literature of his own era and after is indisputable. Discussing The Old Man and the Sea, Carey (1973) quotes Hemingway on fiction: "A writer's style should be direct and personal, his imagery rich and earthy, and, his words simple and vigorous. The greatest writers have the gift of brilliant brevity, are hard workers, diligent scholars and competent stylists" (p. 56).

Ellipsis is a means of creating this 'brilliant brevity.' This study is about the translation of ellipsis as a stylistic feature; interestingly, even the above quotation from Hemingway on the art of fiction is itself elliptical which betokens the importance of this feature or device in his prose style.

Halliday \& Hassan (1976) interpret ellipsis as "the form of substitution in which the item is replaced by nothing" (p. 88). Stressing the fact that language does not function in isolation, but rather as a text, in an actual situation of use, they state that although unsaid, ellipsis is referred to cases in which there is a structural gap that can be completed by reference to a related structure in the immediate, usually preceding context, (p. 142). Dividing reduction to two categories of pro-forms and ellipsis, Quirk et al (1985) assert that "such preferences for reduction is not merely a preference for economy; it can also contribute to clarity, by reducing items which are shared as given information, so that will be focused on fresh materials or new information" (p. 860). They further add that the fundamental principle to distinguish ellipsis from other kinds of omission is emphasis on recoverability of the absent parts whose meaning is implied by the textual environment. In a comparative study on the analysis of elliptical sentences in English and Persian, Hashemian Jazi (1989) shows that elliptical structures of any type (i.e. nominal, verbal and clausal) and sub-types are almost similar between the two languages, the main contrast being different occurrence of frequencies in sub-types and some expressions which have no equivalents in the other language.

\section{Research Questions:}

Based on what was stated above, the present study sought to find answers to the following questions:

1. How attentive have the Persian translators of The Old Man and the Sea been to the stylistic features of the original text?

2. What strategies have been adopted by these Persian translators in transferring similar and dissimilar elliptical elements between the two languages?

\section{Methodology}

\section{Materials}


To elucidate Hemingway's elliptically simple style, one of his masterpieces, the noble-prizing-winning The Old Man and the Sea was selected, since it displays the genuine style of the author, is one of the works on which Hemingway's reputation hinges, and is translated into many languages. 5 available Persian translations of this novella were selected to be analyzed stylistically. They are as follows:

“Mard-e Pir va Daryā." by Morteza Yahyavi (1962), "Pir-e Mard va Dar yā" by Nazi Azima (1972), "Pir-e Mard va Dar yā" by Najaf Darya-Bandari (1984), "Pir-e Mard va Dar yā" by Sudabeh Asha (1994), and "Pir-e Mard va Dar $y \bar{a}$ ” by Mohammad Taghi Faramarzi (2006).

\section{Model}

The theoretical framework of the present study is mostly based on the model postulated by Quirk et al (1985) illustrating various types of ellipsis - as something left unsaid, but understood (Widdowson, 1978, p. 211). As a supplement to this model, merely one of the cases offered in Halliday and Hassan's (1976) discussion of ellipsis is also included.

\section{Procedure}

In the present study, the data is descriptively analyzed. First, the English and Persian elliptical structures of the source and target texts are identified and sorted out according to the Model presented by Quirk et al (1985) in order to discover similarities and differences between the two languages. Next, one randomly selected example representing one of 7 main categories is brought forth to check how the elliptical patterns are dealt with in the Persian translations. The aim was to identify the employed strategies by the translators and their efficacy as well as to identify the potential problems related to translation of ellipsis as a feature of style. It has to be noted that in the process of text and data selection different moderator variables such as, length, style, difficulty of texts, etc. are controlled.

\section{DisCUSSION AND DATA ANALYSIS}

The whole text of The Old Man and the Sea was meticulously read and instances of ellipsis were identified. The instances were analyzed according to the model suggested by Quirk et al (1985), supplemented by Halliday and Hassan's. Accordingly, 8 main groups of frequently-recurring elliptical patterns were presented. Following is a discussion of some of the most typical examples of each category of ellipsis. It should be mentioned that, predictably, sometimes a sentence's elliptical structure cuts across a number of these categories of ellipsis. Following are the categories and the relevant examples.

\section{Anaphoric ellipsis}

As the manifestation of textual ellipsis, anaphora can recover the elliptical structure.

(1: 1). "I shouldn't have gone out so far, fish" he said. "Neither for you nor for me. I'm sorry fish." (p. 121)

This example is recoverable according to the features of the anaphoric ellipsis, i.e. the antecedent normally has 'precedence' over the ellipsis construction, by taking an earlier or a higher position in the sentence (Quirk, 1985: p. 895).

"I should have gone so far" is the elliptically inflected part of the underlined sentence that regarding the first sentence is not mentioned in order to highlight the sole presence of the two main characters of the story, the fish and the old man, alone on that vast sea. "The old man has a feeling of brotherhood with all the creatures of nature....there is also a oneness in nature between the man and the great fish" (Carey, 1973: p. 48).

Darya-Bandari has gone beyond the limitations of the sentence and not only translated the omitted part, but also disclosed one of the possible interpretations of the sentence.

مناسفم كه زياد دور رفتم. زندكى هر دو تمان رو خر اب كردم. (p. 208)

The suggested image in the target equivalent is not totally compatible with the original one. This sentence might be the translator's conclusion about the speaker's intentions while addressing the fish and as a matter of fact, limiting the borders and layers of meaning, the Persian equivalent does not let the text to be open enough to be explored by the target reader. (Expansion)

As mentioned before, the omitted elements could be recovered according to the first sentence, not the following one. Unaware of the author's style as well as the grammatical structures, Azima has wrongly taken the last sentence, i.e. "I'm sorry." as the coordinated sentence.

$$
\text { ماهى، نبايد اينهمه دور ميرفتم. هم به خاطر تو و هم ببه خاطر خودم متاسفم. }
$$

She has mixed the second and the third sentences and whereby marred the image of the loneliness of the characters.

(p. 201)

The above sentence is Faramarzi's. Literally viewed, the translation renders the sense and the sound and proves its loyalty to the original.

Making Darya-Bandari's mistake, Yahyavi has rendered the source text as

ماهى من نميباسيتى اين همه دور رفته باثُم. اين كار بر اي من و تو هر دو خوب نبود.

This is one of the possible meanings of the speaker's quotation, imposing the same limitations on the target reader.

Asha has been pretty successful in her translation:

نمى بايست اين همه از ساحل دور ميشدم ماهى. هم به خاطر خودمو هم به خاطر تو.

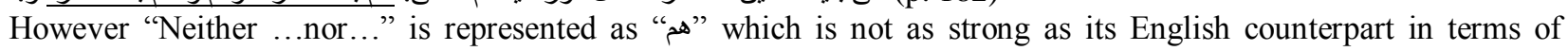
negativity. It should be stated that in the original text these words add to the negative, portentous mood. 


\section{Coordination}

As one of the main sub-categories of special ellipsis, coordinate clauses are linked by words such as "and", "but", and "or" (Quirk et al, 1985: p. 910).

(2:1). "He no longer dreamed of storm, or of women, or of great occurrences, or of great fish, nor fights, nor contest of strength, nor of his wife." (p. 27)

Young (1975) notes that "Hemingway's style is remarkably uncomplicated. Events are described clearly and in the order in which they occurred; the author doesn't change the order or examine the events" (p. 109). In this example, the relatively short sentence exhibits an uncanny directness by stringing together paratactic items, each creating a certain image, through ellipsis. "He dreamed" is the ellipted unit of the underlined parts that is recoverable according to the coordinated sentence. Hence, just images such as women, great occurrences, etc. are mentioned. Considering the order of paratactic phrases in the sentence and the occurrence of ellipsis, Darya-Bandari has translated the sentence literally as,

$$
\text { (p. 116) }
$$

That is the first part includes the verb "خون بزاب ديدن" (to dream) and the following parts are elliptically translated. The translation sounds ideal because it is attentive to both form and content.

Azima has ignored the order and the occurrence of ellipsis and translated all the parts, even the initial clause which does not contain ellipsis, elliptically.

مدتها بود كه ديكر خو اب طوفان، زنان، ماجر اجو ييها، ماهيهاى بزرگ، جنى و جدالها، زور آزماييها و زنش را نميديد.

Although violating the frequency of the occurrence of ellipsis, Faramarzi has translated this part elliptically. The first four paratactic phrases as well as images are mixed into one.

$$
\text { (p. 123) همسرش را. نه ماهيهاى بزرگ، نه زدو خوردها، زور آزماييها و نه او نه ديكر توفانها، زنها، بيشامدهاى بزرگ را در خواب ديد، }
$$

This is Yahyavi's translation:

$$
\text { (p. 45) }
$$

Inattentive to the style, the translator has just rendered the meaning literally and of course not completely, since "nor fight" is not translated.

Like Azima, Asha has ignored the negation elements of the source text as well as the order of the occurrence of ellipsis.

(مدتها بود كه ديكر ،طوفانها، زنها، حو ادث بزرى و ماهيهاى بزرگ، جدال هاو زور آزماييهاو همسرش را در خو اب نميديد.

\section{Elliptical clauses:}

Ellipsis of the clauses is included as a subcategory of functional ellipsis, including ellipsis of the predicate, ellipsis of Wh-clauses, ellipsis of to-infinitive clauses, and ellipsis of an entire clause.

(3: 1). "That's very kind of you;" the old man said." should we eat?" "I've been asking you to," the boy said. (p. 22)

Considering the full form of underlined sentence as "I've been asking you to eat", this example represents the ellipsis of to-infinitive clause. Translation of "to" as the representative of the omitted can be a real challenge for Persian translators.

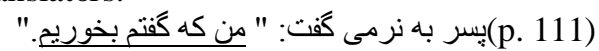

In his translation, Darya-Bandari has added the word "نرمى (softly) which reflects the friendly tone of the speaker. However, the style of the author has been distorted to some extent and the ellipted form, is present in the target sentence. In fact, the translator has expanded the structure.

Recognizing the skipped element of the source structure, Azima has rendered it into Persian as

(p. 33)

In order to make the sentence sound more naturally, she has changed the part into an object pronoun. Although trying to substitute the ellipsis by the pronoun, she has expanded the sentence by the use of not only the pronoun, but also"خودم" (myself).

(Faramarzi, p. 119)

In Faramarzi's translation the ellipted clause has been translated non-elliptically.

Yahyavi's language is closer to the ordinary language of the boy and the old man but his technique in substituting the ellipsis by a pronoun is somewhat the same.

$$
\text { يبرك با محبت جواب داد: من هم همين را مى خي خو استخ. (Yahyavi, p. 38) }
$$

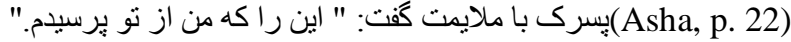

Asha's translation is quite similar to Azima's (apart from the literal translation of the verb "ask").

Generally, all the translators have decided to expand the structure unnecessarily.

\section{Noun Phrase}

Ellipsis of noun phrase as the subcategory of functional ellipsis ,"exept in coordinate noun phrases, result from the final ellipsis" (Quirk etal, 1985, p. 900). It shares the common features with the nominal ellipsis in Halliday and Hassan's model (1976).

(4: 1). "May I get the sardines? I know where I can get four baits too."

.... "One" the old man said. His hope and his confidence had never gone....

"Two" the boy said.

"Two" the old man agreed.

... the boy said. "but I bought these" . (p.13) 
Elliptical noun phrases include final ellipsis, i.e. postmodifiers (if any) and heads tend to be ellipted. "Sardines" is the ellipted noun phrase after "one", "two", and "these" in the marked sentences. While the elliptical sentence can be expressed through a word like "two" representing numeratives or the demonstrateives such as "these", Persian nominal

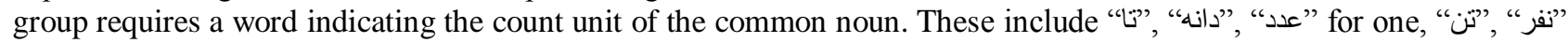
for person, "جفت" for pair, "فروند" for one (plane), "دست" for clothes and etc. (Shariat, 2000). Morover, not only noun phrases but also the clauses are ellipted in the first and second marked sentences. the full form of the sentences are "buy one fresh sardine.", and "I'll buy two sardines".

Keeping this difference between the two languages in mind, Darya-Bandari has transferred the noun phrases elliptically.

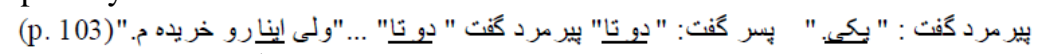

His selection of "تا" in translation for the omitted noun phrases in the target language matches the standard structure of Persian. His strategy to render the mentioned parts has been literal translation in both the cases of noun phrases and clauses.

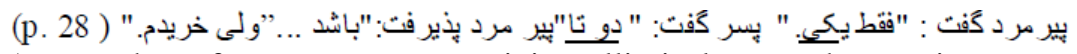

Among these four sentences containing elliptical noun phrases, just two are transferred accuratly by Azima. Her strategy in translation of the third and the fourth sentences is deletion.

(p. 113)

Faramrzi's translation has rendered all the ellipted elements in the noun phrase category This is compatible with Persian grammar but of course translating what is omitted in the original text is a violation of style.

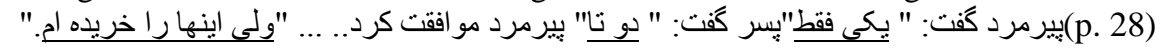

Yahyavi's translation is not quite loyal to the original, for although Persian sentences share the ellipsis with their source counterparts, the third sentence is not translated at all.

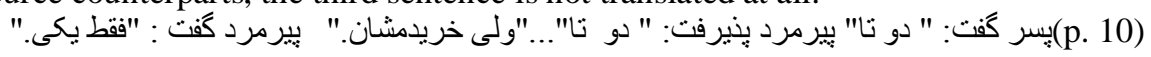

Regarding the stated point about Darya-Bandari's translation, Asha has done her job pretty successfully.

5. Subject+ Operator

The ellipsis of subject operator contains subject + to be. The following example depicts the ellipsis of subject+ operator, i.e. "you were five" is the full manifestation and the subject "I" and the verb "were" are not present. As a result, "five" is the remaining element that, though making sense while rendered literally in Persian, needs to be accompanied by a count unit to sound more natural to the Persian readers. In addition, this example shares the characteristics of "elliptical response" as well.

(5: 1). "How old was I when you first took me in a boat?" "Five and you nearly were killed when I bought the fish...." (p.12)

The first three marked sentences confirm that their translators have done their task successfully and kept the form intact while meadiating between the source and target texts. Considering the related points and deleting the subject " $"$ " and the verb "بودى" (functioning as fele-rabt ('relative verb')in Persian grammar), Darya-Bandari, Azima, and Yahyavi have chosen "سال" for this part to make it more acceptable to the target readers. Apart from ellipsis, Yahyavi's tone and diction does not match that of the original text.

$$
\begin{aligned}
& \text { اولين بار كه منو با قايقت بردى جند سالم بود؟؟ - ينج سال. } \\
& \text { (Azima, p, 27) }
\end{aligned}
$$

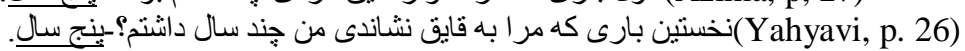

Unlike the previous ones, Faramarzi and Asha have used expansion as their opted strategy in the following and hence, have passed over the ellipsis in its full form.

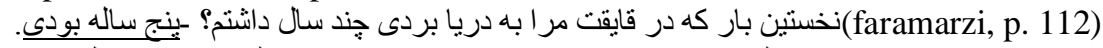

$$
\begin{aligned}
& \text { (Asha, p. 8) }
\end{aligned}
$$

\section{Substitution}

This category accords with the patterns represented in the ellipsis of predication in finite clause, and of 'Do'as stranded operator. The comparative structure is the one comprising the potentiality of DO- support. Nevertheless, considering the point that insertion of the omitted predication after did will result in an unacceptable sentence, this case is not ellipsis, but quasi-ellipsis (Quirk, p. 905).

(6: 1). "Certainly his back cannot feel as badly as mine does." (p.58)

'Does' stands for 'can feel'. Persian grammar makes it almost impossible to match this kind of ellipsis. As a result, adopting almost the same method, all the translations offer one verb for two and hence, respond similarly to the ellipsis.

يشت او حتما به اندازه ى بشت من درد نمى كند. (Darya-Bandari, p. 145)

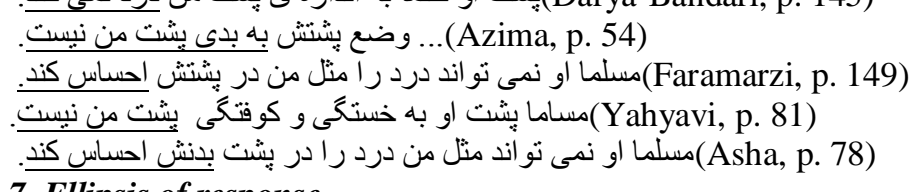

\section{Ellipsis of response}

The selected ellipted responses can be portrayed based on the features of the following categorizations:

1) Ellipsis of the nonfinite part of the verb + its complemet 
In this formula, mentioned as the subdivision of 'Ellipsis of the predication in finite clauses', the modal is present in the sentence while the other following componenets are absent.

(7: 1). "Do you believe the great DiMaggio would stay with a fish.....? I am sure he would." (p. 75)

Although expressed through a modal such as 'would', this omission cannot be equated by the same form in the target language. To restate the matter differently, the typical Persian equivalent bears a grammatical shift, requiring the verb as the essential component in either the shortened or the full form of the sentence.

يقين دارم مى ايستاد. Darya-Bandari, p. 161)

Short and loyal to the form, the translated sentence by Darya-Bandari also manifests the essence of Persian with regard to such patterns. Thus, the predicate is dropped and the verb is inevitably translated.

"(Azima, p. 65)

(Asha, p. 108)

Azima and Asha also employ the same strategy used by the first translator. Their word choices make the difference, though.

(بمتما او همين اندازه يا بيشتر به انتظار خو اهد نشست. (Faramarzi, p. 165)

(Yahyavi, p. 104)

Even though trying to represent the ellipted predicate, the last two translators have expanded the sentence by adding their interpretations.

2) Ellipsis of the predicate

It means that "only part of the clause to remain is the subject... occurs only in certain special constructions, such $\mathrm{s}$ comparative, coordinate, and response constructions" (Quirk et al, 1985, p. 906).

The following response can be an appropriate case since it deals with the ellipsis of the predicate:

(7:2). "Who gave it to you? -: Martin, the owner of the café." (p. 21)

'Martin who is the owner of the café gave it to me.' is the full form of this response. Congruous with the target forms, literal translation fits well and therefore is largely the opted procedure in the target translations.

"(Darya-Bandari, p. 111)

(")" مارتين. صاحب صاحب كافه. (Yahyavi, p. 33)

"(Azima, p. 33)

“ز” is an unnecessary word in this Persian translation resulting in lengthening the sentence.

(Faramarzi, p. 119)

"(Asha, p. 20)

3) Ellipsis of direct response to WH- Questions

Due to the fact that Quirk's model lacks this relevant category the instances of which are found in the collected data, it is taken from Halliday and Hassan's. This is the simplest form of response to a WH- question, on which the appropriate nominal, adverbial or prepositional group act as the subject or complement.

(7:3). "What can I do now? he thought. Nothing. I must think of nothing and wait for the next ones." (p. 123)

This elliptical sentence that consists of just a single word very delicately mirrors the author's art in pithily expressing the main theme of the novel. After passing a long time wandering on the waves and facing various challenges, the old man's hands and boat are empty. In fact, 'nothing' is the only word that depicts his life after fighting the sharks and forfieting his only property, his brother fish. Using this key word in an ambigious way, Hemingway demonstrates his narrative powers. This ambigious ellipsis can refer either to "I can do nothing." as the answer for the mentioned question and function anaphorically, or to "I can think of nothing." and be the cataphoric ellipsis according with its following sentence. The easiest way to keep this ambiguity resulting from Hemingway's ellipical style is the strategy of literal translation allowing the target version to share the inherent features of the source one.

Employing the mentioned strategy, Darya-Bandari, Faramarzi, and Asha have translated this part as,

(Darya-Bandari, p. 204)

(Faramarzi, p. 202)

هينج جيز (Asha, p. 184)

Sharing the stylistic and semantic aspects of the source sentence, this literal translation has the same potential for the target reader to enjoy exploring different layers of the meaning.

باه هيج جيز (Azima, p. 93)

While trying to retain the orginality of the sentence formally and rendering the ellipsis in the target sentence, Azima has narrowed down the range of meanings - an interesting case of the significant consequences of ignorance of style -by adding the preposition "ب̣" that can be a Persian equivalent for "about" in "think about nothing".

بعد به خودش كفت درباره ى هيج جيز نبايد فكر كرد. (Yahyavi, p. 157)

The last sentence is Yahyavi's translation that stylistically bears no similarity to the source sentence. The Persian sentence includes neither ellipsis nor ambiguity and the only rendered meaning is "I' $\mathrm{d}$ rather think about nothing".

\section{Ellipsis of nonfinite and verbless clauses}

(8: 1) "The sail was patched with flour sacks and, furled; it looked like the flag of permanent defeat." (p. 9)

Illustrating the nonfinite clause ellipsis, the marked section could be recovered as "while it was furled...' but highlighting the concrete images describing the old man's only fruit of life, and also intensifying the rhythmic effect of 
the sentence, ellipsis figures as a supreme literary device here. There is a possibility of fidelity to the style through literal translation.

Literally rendered, the first equivalent for the elliptical component functions as an adjectival phrase and thus roughly matches the grammatical framework of the original text. On the contrary, the other two underlined equivalents expand the structure into a full sentence, especially the third one.

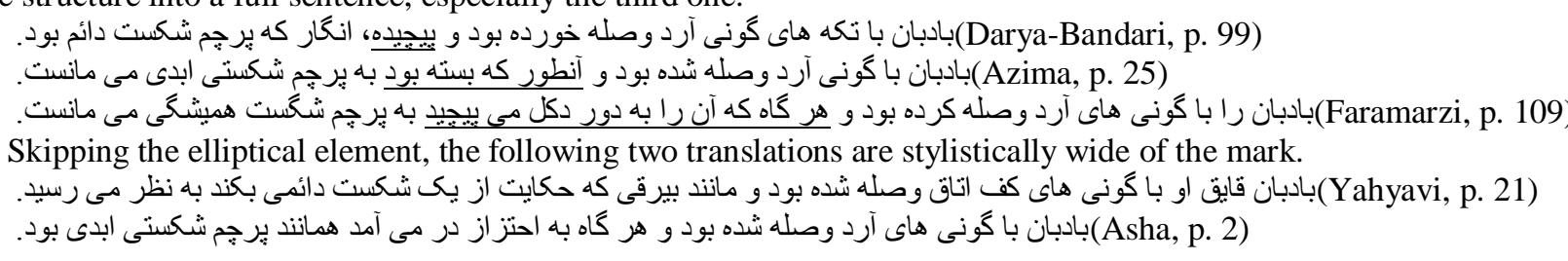

\section{CONCLUSION}

Ellipsis, a fascinating linguistic possibility, involves leaving out certain linguistic elements and yet conveying the meaning; that is, the meaning of the elliptically dropped element is understood. Used as a device or component of style by a great writer, however, ellipsis intimates extra layers of meaning as well. As such, the treatment of this feature in translation offers an ample ground for research. The analysis of the selected examples of the translation of ellipsis in this study, from the Persian translations of a novel by Hemingway, a master of elliptical style, revealed that a great majority of the instances of elliptical patterns acted fairly similarly in both English and Persian. Thus, it seems that the potential Persian translators should not face too many problems in the attempt to keep the originality of the text. In some cases such as substitution, Persian differs from English due to differences in grammatical structures. It was concluded that where the translators have heeded the author's style they have mostly opted for literal translation in rendering ellipsis as a stylistic feature so as to let the reader experience the author's style as closely as possible. Some translators have expanded or deleted the elliptical element, hence deviating from the stylistic norms of the original. It seems that literal translation could be the most efficacious strategy for translating ellipsis as a feature of style in the case of English-into-Persian literary translation as it is exemplified in the translation of one of the most style-conscious of contemporary Persian literary translators, that is, Darya-Bandari.

\section{REFERENCES}

[1] Adams, D. (1939). Ernest Hemingway: The English Journal, Vol. 28, No. 2, Part 1, pp. 87-94.

[2] Asha, S. (1994). Pir-e Mard va Dar yā. Tehran: Rahnamā.

[3] Azima, N. (1975). Pir-e Mard va Dar yā. Tehran: Amir Kabir.

[4] Benjamin, W. (1923). The Task of the Translator. In Venuti, L. (Ed.) (2000). The Translation Studies Reader. London and New York: Routledge.

[5] Bloom, H. (ed.), (1987). Modern Critical Interpretations: Ernest Hemingway's The Sun Also Rises, New York: Chelsea House.

[6] Carey, G. (1973). The Old Man and the Sea Notes. Lincoln, Nebraska: Cliffs Notes.

[7] Emami, K. (1993). Pasti va Bolandi hā -ye Tarjome. Tehran: Nilufar.

[8] Darya-Bandari, N. (1984). Pir-e Mard va Daryā. Tehran: khārazmi.

[9] Faramarzi, M. T. (2006). Pir-e Mard va Dar yā. Tehran: Negāh.

[10] Habib, M. A. R. (2005). A History of Literary Criticism. Oxford: Blackwell.

[11] Halliday, M., \& Hasan, H. (1976). Cohesion in English. London: Edward Arnold.

[12] Hatim, B. (2001). Teaching and Researching Translation. London: Longman.

[13] Hashemian Jazi, H. (1989). A Contrastive Analysis of English and Persian Ellipsis. (Unpublished Master's Thesis). Shiraz University, Shiraz, Iran.

[14] Hemingway, E. (1952). The Old Man and the Sea. New York: Charles Scribner's Sons.

[15] Jones, F. (2000). The Poet and the Ambassador: Communicating Mak Dizdar's Stone Sleeper, Translation and Literature, Vol. 9 , No. 1 , pp. 65-87.

[16] Landers, C. E. (2001). Literary Translation, A Practical Guide. UK: Multilingual matters LTD.

[17] Nida. E (1964). Principles of Correspondence. In Venuti, L. (Ed.) (2000). The Translation Studies Reader. London and New York: Routledge.

[18] Nabokov. V. (1955). Problems of Translation: Onegin in English. In Venuti, L. (Ed.) (2000). The Translation Studies Reader. London and New York: Routledge.

[19] Quirk et al. (1985). A Comprehensive Grammar of the English Language. London \& New York: Longman.

[20] Shariat, M. J. (2000). Dastur Zabān-e fārsi. Tehran: Asātir.

[21] Toolan, M. (1990). The Stylistics of Fiction. London: Routledge.

[22] Weshler, R. (1998). Performing Without a Stage. North Haven, CT: Catbird.

[23] Yahyavi, M. (1962). Mard-e Pir va Daryā. Tehran: Marefat.

[24] Young, P. (1975). Modern American Novelists. New York: Washington Square Press.

Arezou Nezam was born in 1987. She received a BA in English literature in 2009 and an MA in translation studies in 2011 from University of Isfahan, Iran. 
Hossein Pirnajmuddin is an Assistant Professor of English Literature at University of Isfahan, Iran, where he has taught since the completion of his $\mathrm{PhD}$ at University of Birmingham, UK, in 2002. His interests include Renaissance literature, colonial and postcolonial theory, postmodern fiction and translation studies. 